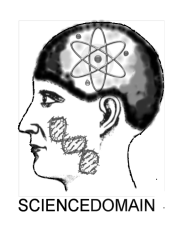

\title{
Diagnostic and Prognostic Value of Procalcitonin in Tuberculosis Patients
}

\author{
K. Rohini ${ }^{1^{*}}$, Surekha Bhat ${ }^{2}$, P. S. Srikumar ${ }^{3}$ and A. Mahesh Kumar ${ }^{4}$ \\ ${ }^{1}$ Unit of Biochemistry, Faculty of Medicine, AIMST University, Bedong, Kedah, Malaysia. \\ ${ }^{2}$ Former Head in Foundation Science, Melaka Manipal Medical College, Melaka, Malaysia. \\ ${ }^{3}$ Unit of Psychiatry, Faculty of Medicine, AIMST University, Bedong, Kedah, Malaysia. \\ ${ }^{4}$ Pulmonologist, Madras Medical Mission Hospital, Chennai, India.
}

\begin{abstract}
Authors' contributions
Author KR designed the study, managed the literature searches, performed the statistical analysis, wrote the protocol, and wrote the first draft of the manuscript. AuthorsSB and PSS managed the analyses of the study. Author AMK managed the sample collection. All authors read and approved the final manuscript.
\end{abstract}

Research Article

Received $5^{\text {th }}$ April 2013

Accepted $18^{\text {th }}$ July 2013

Published 23 ${ }^{\text {rd }}$ July 2013

\section{ABSTRACT}

Aims: Procalcitonin, the prohormone precursor of calcitonin rises in serum response to bacterial infections. Circulating PCT levels decrease when the infection is controlled by the host immune system or antibiotic therapy. The present study was conducted to measure the diagnostic and prognostic utility of procalcitonin in tuberculosis.

Methodology: The study group consisted of forty patients with pulmonary tuberculosis (PTB) and forty normal controls (NC). Blood was collected from NC and PTB (labeled as PTB-0). Patients underwent the 4-drug chemotherapy for 2 months following which blood was collected again (labeled as PTB-2). They were continued into the next 4 months of the 2-drug regimen. Blood was collected thereafter and labeled as PTB-6. All blood samples were semiquantitatively analyzed for procalcitonin.

Results: Serum PCT was $<0.5 \mathrm{ng} / \mathrm{ml}$ in thirty seven out of forty normal controls and $>2$ $\mathrm{ng} / \mathrm{ml}$ in three. The prohormone level was $>2 \mathrm{ng} / \mathrm{ml}$ in fifteen and $>10 \mathrm{ng} / \mathrm{ml}$ in the rest of the PTB-0 subjects, thus indicating that PCT levels served as a useful marker of infection in PTB patients at diagnosis. After 2 months of intensive treatment the number of patients with PCT levels $>10 \mathrm{ng} / \mathrm{ml}$ increased to thirty two in PTB-2. Only 8 patients recorded plasma PCT levels $>2 \mathrm{ng} / \mathrm{ml}$. At the end of 6 months of treatment, PCT values 
in all patients had decreased to $<2 \mathrm{ng} / \mathrm{ml}$.

Conclusion: Serum PCT seemed to show diagnostic and prognostic utility at the end of treatment however, PCT is not specific for tuberculosis alone and may be raised in other lung infections. Future studies with quantitative analysis of PCT in tuberculosis in comparison to other lung infections are needed for better understanding of the role of PCT in PTB.

Keywords: Procalcitonin; tuberculosis; diagnosis; prognosis.

\section{INTRODUCTION}

Procalcitonin is the prohormone precursor of calcitonin that is expressed primarily in C-cells of the thyroid gland and to a smaller extent in neuroendocrine tissue of other organs, such as lungs and intestines. The level of procalcitonin in the blood stream of healthy individuals is below the limit of detection $(10 \mathrm{pg} / \mathrm{mL})$ of clinical assays [1] and rises in a response to a proinflammatory stimulus, especially of bacterial origin. It shows a favorable kinetic profile for use as a clinical marker in bacterial infections. It promptly increases within 6 to 12 hours upon stimulation and circulating PCT levels halve daily when the infection is controlled by the host immune system or antibiotic therapy. Serum PCT has been reported as a useful biomarker for diagnosis and prognosis of CAP by several researchers [2-5]. However, most studies [6-8] have reported that serum PCT was not elevated significantly in pulmonary tuberculosis. Baylan and his team have reported that PCT level was not a reliable indicator in the diagnosis of active PTB because of its low sensitivity (41.3\%), and PCT test for the presumptive diagnosis of PTB cannot be a substitute for microbiological, epidemiological, clinical and radiological data [9]. On the contrary, Ozlem and his colleagues have reported that PCT could be a good indicator of inflammation in tuberculosis [10]. However, to the best of our knowledge, there are very few studies reporting the prognostic value of procalcitonin in tuberculosis. The present study was conducted with the aim of estimating the diagnostic and prognostic utility of procalcitonin in pulmonary tuberculosis.

\section{MATERIAL AND METHODS / EXPERIMENTAL DETAILS / METHODOLOGY}

\subsection{Subjects}

The study subjects were recruited from The Institute of Thoracic Medicine, Chennai, India. The study group consisted of forty patients (25-75 yrs.) diagnosed with pulmonary tuberculosis (PTB) and all the patients were smear positive cases. The diagnosis of tuberculosis was performed using Ziehl-Neelsen staining method for Acid-fast Microscopy (AFM) and culture for growth of the organism on Lowenstein-Jensen (LJ) medium. The patients were also tested for radiographic abnormalities. Forty age and sex matched healthy volunteers (Normal controls; NC) were included in the study for comparison of results. The study protocol was approved by the Institutional ethics committee and was carried out in accordance with the principle of Declaration of Helsinki. Informed consent was obtained from all the subjects.

\subsection{Sampling and Analysis}

Blood samples were collected from both groups and those collected from PTB were subgrouped as PTB-0 (PTB at diagnosis), PTB-2 (PTB during treatment or PTB at 2 months 
post treatment) and PTB-6 (PTB at the end of treatment or PTB at 6 months post treatment). Blood samples were collected in PTB-0 immediately after diagnosis and these patients were put under intensive phase of chemotherapy with the four-drug regimen (Rifampicin, Isoniazid, Pyrazinamide and Streptomycin) for 2 months. At the end of 2 months, blood samples were collected again for the estimation of the prohormone levels and these samples were labeled as PTB-2. All the PTB subjects were continued into the next 4 months of continuation phase of treatment with the 2 drug regimen (Rifampicin and Isoniazid). At the end of 6 months, all subjects were declared as clinically cured. Blood samples were collected yet again and labeled as PTB-6.Blood samples thus collected using standard sampling techniques were centrifuged to obtain serum that was analyzed for procalcitonin.

\subsubsection{Definition of new smear positive cases}

A new patient was defined as a TB patient who has never had treatment for TB or one who has taken anti-TB drugs for less than one month. A smear positive patient was defined as a patient with at least 2 initial sputum smear examinations (direct smear microscopy) positive for acid-fast bacilli (AFB) or a patient with one sputum examination positive for AFB and radiographic abnormalities consistent with active pulmonary TB as determined by the treating Medical Officer (MO) or a patient with one sputum specimen positive for AFB and culture positive for M. tuberculosis.

\subsubsection{Definition of clinically cured patients}

TB patients declared clinically cured included patients who were initially sputum smearpositive patient, who had complied with and completed treatment and had negative sputum smears, on at least two occasions, one of which was at the end of treatment.

\subsection{Semiquantitative Analysis of Serum PCT by B.R.A.H.M.S Kit}

Serum procalcitonin was determined by PCT-Q kit (Immunochromatografic test for the determination of PCT in human serum [11]. The B.R.A.H.M.S PCT-Q is an immunochromatografic test for the semi-quantitative detection of PCT. The test employs a sandwich complex formation of PCT in the test sample with a monoclonal mouse anticalcin antibody conjugated with colloidal gold(tracer) and a polyclonal sheep anticalcitonin antibody (solid phase), both present in the kit reagent. At a PCT concentration $\geq 0.5 \mathrm{ng} / \mathrm{ml}$, this sandwich complex can be seen as a reddish band. The color intensity of the band is directly proportional to the PCT concentration of the sample and is related to the following PCT concentration ranges with the help of a reference card: $<0.5 \mathrm{ng} / \mathrm{ml} ; \geq 0.5$ and $<2 \mathrm{ng} / \mathrm{ml}$ (value expressed as $<2 \mathrm{ng} / \mathrm{ml}$ ); $\geq 2$ and $<10 \mathrm{ng} / \mathrm{ml}$ (value expressed as $>2 \mathrm{ng} / \mathrm{ml}$ ); $\geq 10$ $\mathrm{ng} / \mathrm{ml}$.

\section{RESULTS AND DISCUSSION}

The clinical characteristics of tuberculosis patients are presented in Table 1. The results of PCT estimation in NC and PTB-0 are shown in Table 2. Serum PCT levels in thirty seven out of forty normal controls were $<0.5 \mathrm{ng} / \mathrm{ml}$ and three showed PCT values of $>2 \mathrm{ng} / \mathrm{ml}$. However, PCT levels in fifteen out of forty PTB-0 subjects were $>2 \mathrm{ng} / \mathrm{ml}$ and the rest of the PTB-0 subjects showed PCT levels $>10 \mathrm{ng} / \mathrm{ml}$, thus indicating that PCT levels served as a useful marker of infection in PTB patients at diagnosis. Results of PCT estimation after 2 
months of intensive treatment (Table 1) shows that the number of patients with PCT levels > $10 \mathrm{ng} / \mathrm{ml}$ seemed to have increased from 25 at diagnosis to 32 in PTB-2. Only 8 patients recorded plasma PCT levels $>2 \mathrm{ng} / \mathrm{ml}$ as opposed to 15 at diagnosis. Of the total 40 patients, PCT values of 21 patients remained the same as at diagnosis ( 5 patients with PCT $>2 \mathrm{ng} / \mathrm{ml}$ at diagnosis as well as at 2 months post treatment and 16 patients with PCT $>10$ $\mathrm{ng} / \mathrm{ml}$ at both times), 3 patients decreased from $>10 \mathrm{ng} / \mathrm{ml}$ at diagnosis to $>2 \mathrm{ng} / \mathrm{ml}$ at 2 months post treatment and 16 patients increased from $>2 \mathrm{ng} / \mathrm{ml}$ at diagnosis to $>10 \mathrm{ng} / \mathrm{ml}$ at 2 months post treatment. At the end of 6 months of treatment, PCT values in all patients had decreased to $<2 \mathrm{ng} / \mathrm{ml}$ (Table 1). Thus, unlike the unpredictable alterations in PCT at the end of 2 months of intensive treatment, PCT seemed to have predictably decreased in all patients after the continuation phase of treatment.

Table 1.Clinical Characteristics of tuberculosis patients

\begin{tabular}{ll}
\hline Clinical Characteristics & No. of Subjects \\
\hline Total Number & 40 \\
Age & $25 \pm 75$ years \\
Basal Metabolic rate & 30 \\
Severe Malnutrition $\left(<15.9 \mathrm{~kg} / \mathrm{m}^{2}\right)$ & 7 \\
Moderately $\left(16-16.9 \mathrm{~kg} / \mathrm{m}^{2}\right)$ & 2 \\
Mild $\left(17-18.4 \mathrm{~kg} / \mathrm{m}^{2}\right)$ & 1 \\
Normal> $\left.18.5 \mathrm{~kg} / \mathrm{m}^{2}\right)$ & 40 \\
Cough & $25-30$ \\
Fever & 40 \\
Weight loss & $25-30$ \\
Night sweats & \\
\hline
\end{tabular}

Table 2.Serum PCT levels $(\mathrm{ng} / \mathrm{ml})$ in normal controls and pulmonary tuberculosis patients at diagnosis, PTB-0, 2 months post treatment, PTB-2 and 6 months post treatment, PTB-6 ( $\mathrm{n}=40$ for all) according to Triage kit grading (PCT values $>2 \mathrm{mg} / \mathrm{ml}$ and $>10 \mathrm{ng} / \mathrm{ml}$ )

\begin{tabular}{lllll}
\hline PCT range (in $\mathbf{n g} / \mathbf{m l})$ & \multicolumn{4}{c}{ Number of patients } \\
\cline { 2 - 5 } & Normal controls & PTB-0 & PTB-2 & PTB-6 \\
\hline$<0.5$ & 37 & - & - & - \\
$\geq 0.5 \&<2$ & - & - & - & 40 \\
$\geq 2 \&<10$ & 3 & 15 & 8 & - \\
$\geq 10$ & - & 25 & 32 & - \\
\hline
\end{tabular}

In the present study, PCT levels in fifteen out of forty PTB-0 subjects were $>2 \mathrm{ng} / \mathrm{ml}$ and the rest of the PTB-0 subjects showed PCT levels $>10 \mathrm{ng} / \mathrm{ml}$ (whereas, serum PCT levels in thirty seven out of forty normal controls were $<0.5 \mathrm{ng} / \mathrm{ml}$ and three showed PCT values of $>$ $2 \mathrm{ng} / \mathrm{ml}$ ) thus indicating that PCT levels served as a useful marker of infection in PTB patients at diagnosis. These findings have been already discussed elsewhere by the authors of the present study $[12,13]$. PCT levels increase with the increasing severity of the inflammatory response to infection and may help in assessing the severity of infection, the prognosis of disease, and the response to therapeutic measures [14-16]. At first cytokinestimulated adherent monocytes release PCT in low quantities $(<2 h)$. This synthesis is limited but plays an important role in the initiation of a PCT burst in all storage tissues in humans (>18h). The PCT burst continues as long as the stimulus for synthesis exists 
[17].Interestingly, in the present study, PCT levels in 25 out of 40 PTB- 0 patients was $>10$ $\mathrm{ng} / \mathrm{ml}$, a level which, by current guideline of outcome set by B.R.A.H.M.S, is indicative of sepsis. However, all the 25 patients were clinically stable and none of them were reported to go into sepsis but on the other hand, were clinically responding to treatment. Thus, it can be said that although PCT seems to be a good diagnostic marker in tuberculosis, predictive cutoff levels to grade the disease cannot be set without further research correlating the levels of the classical cytokines and the number of bacterial organisms in circulation with PCT levels and without understanding the effect of bacterial infection on the individual steps of CT synthesis from PrePCT to PCT to CT.

In the present study, after 2 months of intensive treatment, PCT values of $52 \%$ of the patients remained the same as at diagnosis, $8 \%$ decreased from $>10 \mathrm{ng} / \mathrm{ml}$ at diagnosis to $>2 \mathrm{ng} / \mathrm{ml}$ and $40 \%$ increased from $>2 \mathrm{ng} / \mathrm{ml}$ at diagnosis to $>10 \mathrm{ng} / \mathrm{ml}$ at 2 months post treatment. These findings are contrary to those of Zarka and his team who investigated PCT levels in patients with respiratory tract infections caused by different etiologies [18]. They found normal serum PCT levels in a limited number of pulmonary tuberculosis cases and also reported that these levels were not correlated with disease severity. Although the present findings per se speak of a low prognostic utility for PCT, there are several factors to consider before the authors can draw a conclusion from these findings. Firstly, the patients included in the present study were from a rural set-up and to ensure that they comply with treatment and do not default it, they were approached personally to collect blood samples for the cause of this research. Since most of them stayed far away from the hospital, the followup time given to them was after 6 months and not 2 months, for the success of the DOTS programme. Hence, it was not possible to calculate the sputum smear conversion rate at the end of 2 months of intensive treatment and the bacterial titre in each patient was not measured to see if there is any relationship between the prevailing high/ increased PCT levels in serum and the bacterial burden at the time of drawing blood for PCT estimation. Finally, since bacterial infections are known to release endotoxins and proinflammatory cytokines that induce the PCT gene, variations in the MTB strains could result in differential actions on the PCT gene by different strains. Although all the patients were new smear positive cases, it was not microbiologically confirmed if all were infected with the same strain.

At the end of 6 months of treatment in the present study, PCT values in all patients had decreased to $<2 \mathrm{ng} / \mathrm{ml}$. Thus, unlike the unpredictable alterations in PCT at the end of 2 months of intensive treatment, PCT seemed to have predictably decreased in all patients after the continuation phase. Interestingly, at the end of 6 months, sputum smear conversion rate was $100 \%$ and all patients were declared clinically cured. In tuberculosis, the influx of PMN to the lung is one of the first events in the pathogenesis of the disease. Studies suggest that macroautophagy contributes to the eradication of MTB from host cells. The initial stages of MTB infection occur within alveolar macrophages that encounter inhaled droplets containing the organism. These previously unstimulated macrophages succeed in internalizing MTB bacteria by phagocytosis. However, the phagocytic vesicles containing MTB fail to fuse with lysosomes [19], because of MTB virulence factors that alter the phospholipid structure of the phagosome membrane [20-22]. As such the vesicles become protected niches that support unchecked MTB replication, which leads to the eventual lysis of the infected macrophages, often within mediastinal lymph nodes. Kim and his colleagues have demonstrated that isoniazid and pyrazinamide promote autophagy activation and phagosomal maturation in Mycobacterium tuberculosis -infected host cells [23]. During the 2 months of treatment with the 4 drug regimen, the antibiotics are expected to start producing their beneficial effect on host cell immunity and at the end of 6 months; rifampin and 
isoniazid are expected to complete the action of resolving the altered host defence by the bacterial burden. In the present study, it seems that due to successful antituberculous treatment, the bacterial infection was eliminated at the end of 6 months and with the removal of the stimulant for PCT synthesis, the prohormone levels have come back to normal. Although we could not make a clearly conclusive statement on the prognostic utility of PCT at the end of 2 months of intensive treatment, the prohormone seems to be a good prognostic marker for the efficacy of the 6 months treatment. However, at the end of this research with the prohormone, we feel that future research should aim more at cracking the mechanism of increase / no increase in PCT during tuberculosis. The semiquantitative estimation of PCT was a limitation as we could not calculate the correlation coefficient of serum PCT with other parameters. A study on all the sites of action of bacterial endotoxins or proinflammatory cytokines in the pathway of synthesis of calcitonin from PrePCT through PCT could open avenues for new drugs to be targeted at these specific sites.

\section{CONCLUSION}

Serum PCT showed a tremendous increase above the normal cut-off, in all the patients at diagnosis. After 2 months of intensive phase of treatment, the number of patients with an increase in PCT was more than those with decrease or no change in the prohormone levels. Although a clearly conclusive statement on the prognostic utility of PCT cannot be made at the end of 2 months of intensive treatment, the prohormone seems to be a good prognostic marker for the efficacy of the 6 months treatment, because at the end of 6 months, PCT in all patients had decreased albeit not below the normal cut-off of $<0.5 \mathrm{ng} / \mathrm{ml}$. Although our study showed that PCT may have a diagnostic and prognostic utility at the end of treatment, however, it is not specific for tuberculosis alone and may be raised in other lung infections. Serum PCT seemed to be raised in PTB patients and dropped down to normal at the end of treatment; However, this does not warrant us to call it a good diagnostic marker for PTB because it is raised in other lung diseases also. Future studies with quantitative analysis of PCT in tuberculosis in comparison to other lung infections are needed for better understanding of the role of PCT in PTB.

\section{CONSENT}

All authors declare that 'written informed consent was obtained from the patient for sample collection.

\section{ETHICAL APPROVAL}

All authors hereby declare that all experiments have been examined and approved by the appropriate ethics committee and have therefore been performed in accordance with the ethical standards laid down in the 1964 Declaration of Helsinki.

\section{COMPETING INTERESTS}

Authors have declared that no competing interests exist. 


\section{REFERENCES}

1. Dandona $P$, Nix D, Wilson MF, et al. Procalcitonin increase after endotoxin injection in normal subjects. J. Clin. Endocrinol. Metab. 1994;79(6):1605-08.

2. Christ-Crain M, Stolz D, Bissinger R, Müller C, Miedinger D, Huber P.R, Zimmerli W, Harbarth St, Tamm M and Müller B. Procalcitonin guidance of antibiotic therapy in community-acquired pneumonia. Am J RespirCrit Care Med. 2006;174:84-93.

3. Nyamande K, Lalloo UG. Serum procalcitonin distinguishes CAP due to bacteria, Mycobacterium tuberculosis and PJP. Int J Tuberc Lung Dis.2006;10(5):510-15.

4. Schuetz P, Christ-Crain M, Thomann R, et al. Effect of procalcitonin-based guidelines vs standard guidelines on antibiotic use in lower respiratory tract infections: the ProHOSP randomized controlled trial. JAMA. 2009;302:1059-66.

5. Ugajin M, Miwa S, Shirai M, Ohba H, Eifuku T, Nakamura H, Suda T, Hayakawa H, Chida K. Usefulness of serum procalcitonin levels in pulmonary tuberculosis. EurRespir J. 2011;37(2):371-5.

6. Kang YA, Kwon SY, Yoon $\mathrm{HI}$, et al. Role of $\mathrm{C}$-reactive protein and procalcitonin in differentiation of tuberculosis from bacterial community acquired pneumonia. Korean $\mathrm{J}$ Intern Med. 2009;24:337-342.

7. Polzin A, Pletz M, Erbes R, Raffenberg M, Mauch H, Wagner S, Arndt G, Lode1 H. Procalcitonin as a diagnostic tool in lower respiratory tract infections and tuberculosis. EurRespir J. 2003;21:939-43.

8. Schleicher GK, Herbert V, Brink A, et al. Procalcitonin and C-reactive protein levels in HIV-positive subjects with tuberculosis and pneumonia. EurRespir J. 2005; 25:68892.

9. Baylan O, Balkan A, Inal A, Kisa O, Albay A, Doganci L, et al. The predictive value of serum procalcitonin levels in adult patients with active pulmonary tuberculosis. Jpn J Infect Dis. 2006; 59:164-7.

10. Özlem K, Bahar U, Gürbüz P, Canan S, Handan C, Ali K. Elevation of procalcitonin level in patients with pulmonary tuberculosis and in medical staff with close patient contact. Archives of medical research. 2003;34(4):311-4.

11. Meisner M. Procalcitonin - Biochemistry and clinical diagnosis. ISBN 978-3-83741241-3, UNI-MED, Bremen. 2010.

12. Rohini K. Diagnostic and prognostic value of procalcitonin in tuberculosis patients, Ph.D thesis, Banasthali University ('A' Accredited Institution), Rajasthan, 2013.

13. Rohini K, Srikumar P S, JyotiSaxena, Mahesh Kumar A, SurekhaBhat. Assessment of Serum Calcium, Phosphorus, C-reactive protein and Procalcitonin in Tuberculosis Patients. International Journal of Collaborative Research on Internal Medicine \& Public Health. 2012;4(12):1868-75.

14. Frieden TR, Sterling TR, Munsiff SS, Watt CJ, Dye C: Tuberculosis. Lancet. 2003;362:887-99.

15. Chirouze C, Schuhmacher H, Rabaud C, Gil H. Low serum procalcitonin level accurately predicts the absence of bacteremia in adult patients with acute fever. Clin. Infect. Dis. 2002;35:156-61.

16. Janota J, Simak J, Stranak Z. Procalcitonin - a marker of systemic infection and multiorgan dysfunction: characteristics of the gene and protein. Cesk. Fysiol. 2001;50:119-24.

17. Linscheid P, Seboek D, Schaer D, Zulewski H, Keller U and Müller B. Expression and secretion of procalcitonin and calcitonin gene-related peptide by adhaerent monocytes and by macrophage-activated adiposities. Crit Care Med. 2004;32:1715-21. 
18. Zarka V, Valat C, Lemarie E, Boissinot E, Carre P, Besnard, J.C and Doit, P. Serum procalcitonin and respiratory tract infections. Rev. Pneumol.clin. 1999;55:365-69.

19. Armstrong JA, Hart PD. Response of cultured macrophages to Mycobacterium tuberculosis, with observations on fusion of lysosomes with phagosomes. $J$ Exp Med.1971;134:713-40.

20. Shui W, Petzold CJ, Redding A, Liu J, Pitcher A, Sheu L, Hsieh TY, Keasling JD, Bertozzi CR. Organelle membrane proteomics reveals differential influence of mycobacterial lipoglycans on macrophage phagosome maturation and autophagosome accumulation. J Proteome Res. 2011;10:339-48.

21. Kang PB, Azad AK, Torrelles JB, Kaufman TM, Beharka A, Tibesar E, DesJardin LE, Schlesinger LS.The human macrophage mannose receptor directs Mycobacterium tuberculosis lipoarabinomannan-mediated phagosome biogenesis. J Exp Med. 2005;202:987-99.

22. Hmama Z, Sendide K, Talal A, Garcia R, Dobos K, Reiner NE. Quantitative analysis of phagolysosome fusion in intact cells: inhibition by mycobacterial lipoarabinomannan and rescue by an 1a,25-dihydroxyvitamin $D_{3}$-phosphoinositide 3-kinase pathway. $J$ Cell Sci. 2004;117:2131-40.

23. Kim JJ, Lee HM, Shin DM, Kim W, Yuk JM, Jin HS, Lee SH, Cha GH, Kim JM, Lee ZW, Shin SJ, Yoo H, Park YK, Park JB, Chung J, Yoshimori T, Jo EK. Host cell autophagy activated by antibiotics is required for their effective antimycobacterial drug action. Cell Host Microbe. 2012;11(5):457-68.

(c) 2013 Rohini et al.; This is an Open Access article distributed under the terms of the Creative Commons Attribution License (http://creativecommons.org/licenses/by/3.0), which permits unrestricted use, distribution, and reproduction in any medium, provided the original work is properly cited.

Peer-review history:

The peer review history for this paper can be accessed here: http://www.sciencedomain.org/review-history.php?iid=205\&id=12\&aid=1717 